Chiara Picciau, PhD., LL.M.,

Post-Doctoral Research Fellow in Business and Company Law, Bocconi University, Italy

Emanuele Rimini, J. D.,

Full Professor of Business and Company Law, University of Milan, Italy

\title{
EMPOWERING CORPORATE CONSTITUENCIES \\ IN THE EUROPEAN UNION: THE LIMITS AND CHALLENGES OF NON-FINANCIAL DISCLOSURE*
}

\section{KORPORĀCIJU IESPĒJOŠANA EIROPAS SAVIENĪBĀ: NEFINANŠU INFORMĀCIJAS ATKLĀŠANAS ROBEŽAS UN IZAICINĀJUMI}

\begin{abstract}
Kopsavilkums
Līdz ar lielo transnacionālo korporāciju paplašināšanos, kā arī vides problēmu un klimata pārmainu saasināšanos valstu un starptautiskie likumdevēji arvien intensīvāk meklē iespējas korporatīvās sociālās atbildības veicināšanai. Lielās korporācijas faktiski atrodas privilegétā stāvoklīi, kas l̦auj ietekmēt gan pozitīvas, gan negatīvas pārmaiņas, ņemot vērā šo korporāciju darbības mērogu un teritoriālo paplašināšanos. Darbojoties dažādās valstīs, tās vienlaikus var savtīgi izmantot tajās pastāvošu atvieglotu normatīvo regulējumu, lai palielinātu savu peḷnu vai arī, gluži pretēji, ar savu darbību uzlabotu darba apstākḷ ievērojamam cilvēku skaitam un nodrošinātu vides aizsardzību pat tad, ja šajās jomās vietējā regulējuma nav vai tas nav pietiekams. Galvenais uzdevums ir atrast visefektīvāko risinājumu, kā virzìt lielo korporāciju spēcīgo ietekmi, lai tā veicinātu pozitīvas sociālās un vides izmaiṇas. Likumdevēji visā pasaulē arvien vairāk pievēršas nefinanšu informācijas atklāšanas regulējumam kā iespējamajam risinājumam. Eiropas Savienības direktīva 2014/95/ES pieprasa atseviškiem lieliem uzṇēmumiem vadības ziņojumā vai atsevišķā paziņojumā iekḷaut informāciju par dažādiem nefinanšu jautājumiem, sākot ar vides, sociālajiem un darba ņēmēju aspektiem un beidzot ar cilvēktiesību ievērošanu, pretkorupcijas un kukuļošanas novēršanas pasākumiem. Dalībvalstis tiek aicinātas ieviest konkrētāku regulējumu, lai veicinātu pārskatu sniegšanu par ilgtspēju šajās jomās. Lai gan iecere ir lieliska, pastāv pamats šaubīties, vai tas ir vairāk nekā tikai provizorisks pirmais solis. Atš̌kirībā no finanšu informācijas atklāšanas nefinanšu informācijas atklāšanas noteikumi, standarti un metrika joprojām ir samērā nepietiekami izstrādāti, tāpat kā izpratne par to, kuri vides, sociālie un pārvaldības jautājumi faktiski ietekmē finanšu rādìtājus. Vissvarīgākais ir tas, ka pašreizējā sistēma nav pielāgota iespējamo ieinteresēto pušu dažādībai un neviendabīgumam. Kaut arī finanšu informācijas atklāšana galvenokārt vērsta uz pašreizējiem un potenciālajiem investoriem, nefinanšu informācijas atklāšanai ir lielākas iespējas sasniegt mērḳi, kad tā veiksmīgi sasniedz visas ieinteresētās puses - uzṇēmumu darbiniekus, klientus, piegādātājus, vietējās kopienas un plašu sabiedrības loku, kā arī varas iestādes. Tāpēc nefinansiālās informācijas pielāgošana
\end{abstract}

* Although the article is the result of the discussion among the authors, the introduction and paragraphs 2 and 3 shall be attributed to Chiara Picciau, whilst paragraph 1 and the conclusions shall be attributed to Emanuele Rimini. 
iecerēto saņēmēju vajadzībām ir pirmais un, iespējams, vissteidzamākais solis, lai izveidotu efektīvāku normatīvo instrumentu un atvieglotu šis prasības ieviešanu privātā un valsts līmenī.

Atslēgvārdi: nefinanšu informācijas atklāšana, korporatīvā sociālā atbildība, Direktīva 2014/95/ES, pārskati par ilgtspēju

\section{Summary}

With the growth of large transnational corporations and the worsening of environmental problems and climate change, national and international lawmakers are increasingly focusing on finding new ways to foster corporate social responsibility. Large corporations are, in fact, in a privileged position to affect both positive and negative change because of the scale and territorial extension of their operations. Operating in different countries, they may exploit lower regulatory standards to increase profitability or, conversely, raise the quality of employment and ensure environmental protection for a significant number of people, even when local substantive regulation is lacking or insufficient. a key issue is, therefore, finding the most effective way to channel large corporations' powerful influence to promote positive social and environmental change. Lawmakers from all over the world are increasingly turning to non-financial disclosure regulation as a possible answer. In the European Union, Directive 2014/95/EU requires certain large undertakings to include, either in the management report or in a separate statement, information on a variety of non-financial issues, ranging from environmental, social, and employee matters, to human rights protection and anti-corruption and anti-bribery measures. Member States are then called upon to put in place more specific regulations to foster sustainability reporting in these areas. Despite the admirable intent, there are reasons to doubt that this is more than just a tentative first move. Unlike financial disclosure, rules, standards, and metrics for non-financial disclosure are still to some extent underdeveloped, as is the understanding of which environmental, social, and governance issues actually impact financial performance. Most importantly, the current framework is not tailored to address the variety and heterogeneity of the possible interested parties. While financial disclosure is essentially directed to current and potential investors, non-financial disclosure has greater chances to meet its goal when it successfully reaches all interested parties, which significantly also include employees, customers, suppliers, local communities, and a broad range of public authorities. Adjusting non-financial disclosure to the needs of its intended recipients hence is the first, and perhaps most pressing, step to create a more effective regulatory tool and to facilitate private and public enforcement.

Keywords: non-financial disclosure, corporate social responsibility, Directive 2014/95/ EU, sustainability reporting

\section{Introduction}

In recent years, the corporate social responsibility movement has found stronger allies in national and international lawmakers. ${ }^{1}$ Present and past scandals provided evidence of the disruptive effects that corporate misbehaviour might have on working

For a definition of corporate social responsibility and some considerations regarding its advancement within the European Union, see European Commission. Communication to the European Parliament, the Council and the European Economic and Social Committee "Implementing the Partnership for Growth and Jobs: Making Europe a Pole of Excellence on Corporate Social Responsibility", COM (2006) 136 Final. Available at: https://eur-lex.europa.eu/LexUriServ/LexUriServ.do?uri= COM:2006:0136:FIN:en:PDF [last viewed May 7, 2019]. On the history of corporate social responsibility, see Carroll A. B. a History of Corporate Social Responsibility: Concepts and Practices. In: The Oxford Handbook of Corporate Social Responsibility. Oxford: Oxford University Press, 2008, pp. 19 ff. 
conditions, the environment, and human rights. Public attention regarding these issues has concentrated upon transnational corporations. Operating in multiple countries, they have an opportunity to exploit lower regulatory standards enacted by different governments in order to increase profitability, or even to engage in conduct that would be prohibited or not socially accepted at home. ${ }^{2}$ In many instances, geographical distance and asymmetries of information have enabled transnational corporations to neglect or disregard labour protections, human rights, and environmental safeguards, leaving these and other despicable practices in the dark. When this type of conduct eventually came to light, it called for intervention. For example, in the late 1990s, it became known that the worldwide sportswear champion Nike had tolerated the violation of employment laws and health and safety regulations by some of its Asian subcontractors. Public discovery eventually led to a lawsuit that, significantly, attacked on misrepresentation grounds Nike's statements denying the allegations of the press, ${ }^{3}$ which had brought about negative drawbacks for the company's public image.

More recent examples have shown, however, that these phenomena are not uniquely tied to the possibility of exploiting lower regulatory standards or inefficiencies in public and private enforcement systems abroad. The German car manufacturer Volkswagen, for instance, famously came under the spotlight for having failed to comply with clean air and emission regulations, having devised a mechanism to cheat on testing, and having disclosed false information to the public in that respect. ${ }^{4}$ Importantly, these scandals have concerned even purely domestic operations, as well as failures to truthfully report on a variety of environmental, labour, and social issues that typically affect different stakeholders. The scale of operations and size of the enterprises is obviously relevant in drawing a picture of the stakes involved. Large transnational corporations ${ }^{5}$ pose, in fact, unique challenges, including that of ensuring compliance with high environmental, social, and labour protections in different countries with different regulatory frameworks. However, even more limited domestic episodes show the potential magnitude of the effects that corporate wrongdoing can have on different constituencies and public goods.

Because of the scale and territorial extension of their operations, large corporations are also in a privileged position to affect positive change. They may not only exploit lower regulatory standards to increase profitability, but also raise the quality of employment and environmental protections for a significant number of people, even when local substantive regulation is lacking or insufficient. Indeed, as some commentators have noted, given their vast resources and expertise, corporations could very well "have a greater impact on social good than any other institution or philanthropic

2 See Chiu I. H.-Y. Unpacking the Reforms in Europe and the UK Relating to Mandatory Disclosure in Corporate Social Responsibility: Instituting a Hybrid Governance Model to Change Corporate Behaviour? European Company Law Journal, 2017, Vol. 14, No. 5, p. 197.

3 Kasky v. Nike, Inc., 45 P.3d 243 (Cal. 2002).

4 See Zhakypova A. Dissecting Corporate Sustainability Reporting: VW Emissions Scandal case. Available at: https://nature.berkeley.edu/classes/es196/projects/2016final/ZhakypovaA_2016.pdf [last viewed May 6, 2019].

5 Obviously, large is not synonym of transnational, even though the two concepts often overlap. 
organization". ${ }^{6}$ Channelling corporate behaviour towards the pursuit of social and environmental goals has thus become all the more important, to prevent wrongdoing and to bring about positive change. ${ }^{\text {? }}$

National and international lawmakers seem to be aware of this potential. With the expansion across boundaries of corporate activities and the worsening of environmental problems and climate change, they have increasingly focused on finding new ways to foster corporate social responsibility and to direct large corporations' powerful influence to promote positive social and environmental development. Legislative measures in different countries have introduced new organizational forms aimed at pursuing both profit and public benefits. ${ }^{8}$ This led to a renewed scholarly interest on the role of hybrid entities in society. ${ }^{9}$ More generally, recent reforms reignited the debate on whether corporate management should maximize shareholder profits or adopt a stakeholder-oriented perspective. ${ }^{10}$

While hybrid entities' popularity among businesses and lawmakers is perhaps still limited, disclosure-based approaches have obtained broader support at the international level. They are easier to implement and to coordinate among different countries and, at least according to some, they can considerably affect corporate behaviour. ${ }^{11}$ For a long time, many companies have reported on the impact of their activities on workers, the environment, and society on a voluntary basis. ${ }^{12}$ The non-financial

6 Porter M. E., Kramer M. R. Strategy and Society: The Link Between Competitive Advantage and Corporate Social Responsibility. Harvard Business Review, 2006, Vol. 84, No. 12, p. 13.

7 See Esty D. C., Karpilow Q. Harnessing Investor Interest in Sustainability: The Next Frontier in Environmental Information Regulation. Yale Journal on Regulation, 2019, Vol. 36, No. 2, pp. 625 ff. (arguing in favour of a mandatory disclosure regime that would enable investors to distinguish sustainability leaders from laggards and to reward those companies that achieve better sustainability results).

8 Within the United States, the introduction of benefit corporation statutes represents a well-known example. The first statute enabling the formation of benefit corporations was passed in 2010 in Maryland. Among the early scholarly works on the subject, see Brakman Reiser D. Benefit Corporations - a Sustainable Form of Organization? Wake Forest Law Review, 2011, Vol. 46, No. 3, pp. $591 \mathrm{ff}$. The model legislation was advocated by B Lab, a nonprofit organization. See Model Benefit Corporation Legislation (17 April 2017). Available at: https://benefitcorp.net/sites/default/files/ Model\%20benefit\%20corp\%20legislation\%20_4_17_17.pdf [last viewed May 6, 2019]. A similar organizational form, the so-called società benefit, was later introduced in Italy. The relevant provisions are set forth by Italian Law 28 December 2015, No. 2008, paras. 376-384. Available at: https://www. gazzettaufficiale.it/eli/id/2015/12/30/15G00222/sg [last viewed May 6, 2019]. On corporate social responsibility, after the implementation in Italy of Directive 2014/95/EU and the introduction of the società benefit, see, e.g., Angelici C. Divagazioni sulla "responsabilità sociale" d'impresa. Rivista delle società, 2018, No. 1, pp. $3 \mathrm{ff}$.

9 See, e. g., Eldar O. The Role of Social Enterprise and Hybrid Organizations. Columbia Business Law Review, 2017, No. 1, pp. 92 ff.

10 With respect to the US and UK common law systems, see, also for references, Rönnegard D., Craig Smith N. Shareholder Primacy vs. Stakeholder Theory: The Law as Constraint and Potential Enabler of Stakeholder Concerns. Available at: https://papers.ssrn.com/sol3/papers.cfm?abstract_id=3165992 [last viewed May 6, 2019].

11 See Chiu (n. 2), pp. 193 ff. (arguing that mandatory disclosure, operating as a form of indirect procedural regulation, can "encourage effective change in behaviour": p. 205).

12 See, e.g., Quinn J., Connolly B. The Non-Financial Information Directive: An Assessment of Its Impact on Corporate Social Responsibility. European Company Law Journal, 2017, Vol. 14, No. 1, p. 15. See 
disclosure obligations introduced all over the world ${ }^{13}$ intend to take this virtuous initiatives a step further; and where disclosure is not mandatory yet, there is often serious pressure to make it so, ${ }^{14}$ also considering that some of the mentioned scandals did involve failures to truthfully disclose non-financial information. In the European Union, after a few Member States passed national laws on the subject, ${ }^{15}$ non-financial disclosure has become mandatory for large enterprises through the adoption of a harmonization Directive. Questions remain, however, on the effectiveness of the European legislative initiative to encourage positive, concrete change for corporate constituencies.

\section{The European regime of non-financial disclosure}

Already in 2011, the European Commission underscored the importance of improving disclosure and transparency on social and environmental issues by undertakings operating in all sectors, as a tool to enhance long-term growth and development. ${ }^{16}$ After making some amendments to the original proposal, the European lawmaker adopted Directive 2014/95/EU on the disclosure of non-financial and diversity information (the "Directive"). ${ }^{17}$ The Directive does not establish an entirely separate disclosure reporting system, with its own rules and procedures, but amends Directive

also de Roo K. H. M. The Role of the EU Directive on Non-Financial Disclosure in Human Rights Reporting. European Company Law, 2015, Vol. 12, No. 6, p. 279 (discussing the limits of voluntary reporting). On the evolution of sustainability reporting, see Herzig C., Schaltegger S. Corporate Sustainability Reporting. In: Sustainability Communication. Interdisciplinary Perspectives and Theoretical Foundations. Dordrecht: Springer, 2011, pp. 153-156.

13 Cf. United Nations Environment Programme (UNEP), Global Reporting Initiative (GRI), KPMG, Unit for Corporate Governance in Africa. Carrots and sticks - Sustainability reporting policies worldwide - today's best practice, tomorrow's trends. 2010. Available at: https://assets.kpmg/ content/dam/kpmg/pdf/2016/03/Carrots-and-Sticks-11-12-2015.pdf [last viewed May 6, 2019] (finding a significant increase in the number of mandatory reporting obligations. Mandatory disclosure comprised more than two thirds of the policies adopted in the forty-five countries reviewed).

14 For a proposal to introduce sustainable disclosure obligations in the United States, see, e.g., Fisch J. E. Making Sustainability Disclosure Sustainable. The Georgetown Law Journal, 2019, Vol. 107, No. 4, pp. 923 ff.; Esty, Karpilow (n. 7), pp. 662 ff.

15 Before non-financial disclosure obligations were enacted at the European level, some Member States had already put in place non-financial reporting regimes. See Szabó D. G., Sørensen K. E. New EU Directive on the Disclosure of Non-Financial Information (CSR). European Company and Financial Law Review, 2015, Vol. 12, No. 3, pp. 312-313.

16 European Commission. Communication to the European Parliament, the Council, the European Economic and Social Committee and the Committee of the Regions on "A renewed EU strategy 2011-14 for Corporate Social Responsibility”, COM (2011) 681 final. Available at: https://eur-lex. europa.eu/legal-content/EN/TXT/PDF/?uri=CELEX:52011DC0681\&from=EN [last viewed May 7, 2019].

17 Directive 2014/95/EU of 22 October 2014 amending Directive 2013/34/EU as regards disclosure of non-financial and diversity information by certain large undertakings and groups. Available at: https:// eur-lex.europa.eu/legal-content/EN/TXT/PDF/?uri=CELEX:32014L0095\&from=EN [last viewed May 6, 2019]. 
2013/34/EU on annual and consolidated financial statements ${ }^{18}$ in order to include, in the statements of certain reporting companies, non-financial and diversity information.

The Directive focuses only on large undertakings, and covers transparency obligations on a broad spectrum of issues. Disclosure obligations are placed upon publicinterest entities with an average of more than 500 employees during the financial year. ${ }^{19}$ The notion of public-interest entities includes companies whose securities are admitted to trading on a regulated market, credit institutions, insurance companies, and other entities explicitly designated as such by the laws of the Member States. ${ }^{20}$ The new rules, thus, mainly target financial institutions and companies that, regardless of the sector or industry in which they operate, are listed on a regulated exchange. This choice, which is the result of having incorporated non-financial issues in the broader European regulatory framework of financial disclosure, limits the scope of the reform. Size may be a relevant factor in determining which companies should be regulated, either because they have a greater potential to endanger labour conditions, the environment, and society as a whole, or because they can bear the burden of establishing ad hoc procedures and compliance mechanisms. ${ }^{21}$ However, the number of employees might not always be the most effective proxy for size, and access to capital through listing may be equally inconclusive, especially if corporations avoid raising capital on regulated markets. ${ }^{22}$ There is, moreover, no particular reason to target the financial sector over other industries whose activities, such as the production of oil and gas, have notoriously placed the environment or society at risk.

The required information must be included in the management report or in a separate statement ${ }^{23}$ and must enable readers to understand the development, performance, and impact of the entity's activities on a variety of non-financial issues, including at least environmental, social, and employee matters, as well as human rights, anticorruption, and bribery concerns. ${ }^{24}$ The Directive explicitly requires reporting entities to describe their business model, the policies pursued on those issues, including any

18 Directive 2013/34/EU of 26 June 2013 on the annual financial statements, consolidated financial statements and related reports of certain types of undertakings, amending Directive 2006/43/EC of the European Parliament and of the Council and repealing Council Directives 78/660/EEC and 83/349/EEC. Available at: https://eur-lex.europa.eu/legal-content/EN/TXT/PDF/?uri=CELEX: 32013L0034\&from $=\mathrm{EN}$ [last viewed May 6, 2019].

19 Art. 19a(1) of Directive 2013/34/EU, as amended by Directive 2014/95/EU.

20 Art. 2(1) of Directive 2013/34/EU.

21 Recitals (13) and (14) of Directive 2014/95/EU. See the explanatory memorandum accompanying the text of the original proposal: European Commission. Proposal for a Directive of the European Parliament and of the Council amending Council Directives 78/660/EEC and 83/349/EEC as regards disclosure of non-financial and diversity information by certain large companies and groups, COM (2013) 207 final, pp. 6-7. Available at: https://eur-lex.europa.eu/LexUriServ/LexUriServ. do?uri=COM:2013:0207:FIN:EN:PDF [last viewed May 7, 2019]. See also Quinn, Connolly (n. 12), p. 16 (observing that the scope of the original proposal was reduced in order to avoid burdening smaller companies).

22 See, e.g., Gao X., Ritter J. R., Zhu Z. Where Have All the IPOs Gone? Journal of Financial and Quantitative Analysis, 2013, Vol. 48, No. 6, pp. 1663 ff.

23 Art. 19a(4) of Directive 2013/34/EU, as amended by Directive 2014/95/EU. See also recital (6) of Directive 2014/95/EU.

${ }^{24}$ Art. 19a(1) of Directive 2013/34/EU, as amended by Directive 2014/95/EU. 
adopted due diligence procedure, the outcome of such measures, the principal risks in relation to those areas, and the key non-financial performance indicators that are relevant in relation to the entity's business. ${ }^{25}$ The Directive also covers diversity disclosure. Each reporting entity must describe its diversity policy, with specific regards to its application to the entity's administrative, management and supervisory bodies, addressing aspects such as gender, age, professional and educational background, the objectives pursued in this respect, and the results obtained in the reporting period. ${ }^{26}$ Finally, the Directive allows the disclosure to be provided at the group level, consolidating the non-financial reporting of affiliated entities in a single document. ${ }^{27}$

Despite some uniform requirements, the new European rules do not seem to achieve maximum harmonization. ${ }^{28}$ Reporting entities enjoy some flexibility in choosing which widely recognized reporting framework to rely on in their non-financial statements, ${ }^{29}$ and may even partially opt out of their non-financial disclosure obligations. The Directive embraces a "comply or explain" approach, according to which " $[\mathrm{w}]$ here the undertaking does not pursue policies in relation to one or more of [the listed] matters, the non-financial statement shall provide a clear and reasoned explanation for not doing so" ${ }^{30}$ If an entity, for instance, does not have a corporate policy on environmental protection, and it is not otherwise required to adopt and implement one by the law, it does not need to do so simply to comply with its non-financial disclosure obligations, as long as it explains why, under the circumstances, it made that decision. Member States are also called upon to put in place more specific rules to foster sustainability reporting, ${ }^{31}$ potentially introducing variations in the discipline across different countries. The European legislative framework even enables differentiations beyond the mere adoption of disparate implementation rules. Significantly, the Member States

25 Ibid.

26 Art. 20(1)(g) of Directive 2013/34/EU, as amended by Directive 2014/95/EU.

27 Art. 29a of Directive 2013/34/EU, as amended by Directive 2014/95/EU.

28 Szabó, Sørensen (n. 15), p. 318. In its impact assessment accompanying the original proposal, the European Commission specified that the chosen regulatory approach was to introduce minimum harmonization, require disclosure in the annual report, and allow more detailed disclosure on a voluntary basis. See European Commission. Impact Assessment Accompanying the Document Proposal for a Directive of the European Parliament and of the Council amending Council Directives 78/660/EEC and 83/349/EEC as regards disclosure of non-financial and diversity information by certain large companies and groups, SWD (2013) 127 final, pp. 27-30. Available at: https://eur-lex. europa.eu/legal-content/EN/TXT/PDF/?uri=CELEX:52013SC0127\&from=EN [last viewed May 7, 2019].

29 Arts. 19a(1) and 29a(1) of Directive 2013/34/EU, as amended by Directive 2014/95/EU, which provide that reporting entities, either at the company or at the consolidated level, "may rely on national, Union-based or international frameworks" as long as they "specify which frameworks they have relied upon". See also recital (9) of Directive 2014/95/EU.

30 Art. 19a(1) of Directive 2013/34/EU, as amended by Directive 2014/95/EU. a similar provision is set forth by Art. 29a(1) of the same Directive with respect to groups and consolidated non-financial reporting.

31 Most notably, Member States have to make sure that "the members of the administrative, management and supervisory bodies of an undertaking, acting within the competences assigned to them by national law, have collective responsibility" over the non-financial statements and that an auditor or an audit firm check that the information has been provided. See Arts.19a(5), 29a(5), and 33(1) of Directive 2013/34/EU, as amended by Directive 2014/95/EU. 
can broaden the number of non-financial reporting issuers by adding new groups or categories to those already listed as public-interest entities. ${ }^{32}$ They may grant exemptions from the reporting requirements in exceptional cases, if the information concerns impending developments or ongoing negotiations and disclosure would prejudice the commercial position of the reporting entity; ${ }^{33}$ they may require verification by an independent assurance services provider, ${ }^{34}$ and they may allow reporting issuers to include the required non-financial information in a separate report (and not in the management report). ${ }^{35}$

In 2017, the European Commission provided further guidance in a set of guidelines detailing key principles, rules, and criteria to fulfil non-financial reporting obligations (the "Guidelines"). ${ }^{36}$ The Guidelines are not binding, but they should help identify which information to disclose in a brief and yet meaningful manner. They emphasize, for instance, that the information furnished in the non-financial statement should be material to the company's business and activity; ${ }^{37}$ fair, balanced and understandable, including both favourable and unfavourable aspects and with the appropriate context; ${ }^{38}$ comprehensive, but at the same time concise to the extent possible, in accordance with the materiality standard; ${ }^{39}$ strategic and forward-looking, explaining how non-financial issues fit in and intersect with the company's business model and strategies; ${ }^{40}$ consistent and coherent, ${ }^{41}$ and, most importantly, stakeholderoriented. ${ }^{42}$ One of the main goals of the Directive is, in fact, to take into account "the multidimensional nature of corporate social responsibility" and the diversity of the policies implemented in this respect, while at the same time ensuring "a sufficient level of comparability to meet the needs of investors and other stakeholders as well as the need to provide consumers with easy access to information on the impact of

32 Art. 2(1)(d) of Directive 2013/34/EU.

33 Art. 19a(1) of Directive 2013/34/EU, as amended by Directive 2014/95/EU. The exemption may be granted only if the "omission does not prevent a fair and balanced understanding of the undertaking's development, performance, position and impact of its activity”. Member States may introduce a similar exemption with respect to the consolidated non-financial information that certain parent undertakings have to disclose. See, in this respect, Art. 29a(1) of the same Directive.

34 Arts. 19a(6) and 29a(6) of Directive 2013/34/EU, as amended by Directive 2014/95/EU.

35 Arts. 19a(4) and 29a(4) of Directive 2013/34/EU, as amended by Directive 2014/95/EU.

36 European Commission. Communication "Guidelines on non-financial reporting (methodology for reporting non-financial information)”, 2017/C 215/01. Available at: https://eur-lex.europa.eu/legalcontent/EN/TXT/PDF/?uri=OJ:C:2017:215:FULL\&from=EN [last viewed May 7, 2019] (the "Guidelines").

37 Para. 3.1, Guidelines.

38 Para. 3.2, Guidelines.

39 Para. 3.3, Guidelines.

40 Para. 3.4, Guidelines.

41 Para. 3.6, Guidelines. The Guidelines make clear that the non-financial statement should be consistent with the content of the management report, making links and references to its different parts, where needed. The goal is, in fact, to enable investors and stakeholders to understand material information and interdependencies in the disclosure. Consistency should also be ensured over time, making possible to compare between past and current information. Methodologies should, in any case, be updated and changed when new and better ones become available.

42 Para. 3.5, Guidelines. 
businesses on society" ${ }^{43}$ This open-ended formulation makes it clear that the European lawmaker did not simply aim at providing relevant non-financial information to those investors who are paying increasing attention to social and environmental concerns, ${ }^{44}$ but that it also aspires to empower other constituencies, such as workers, customers, and suppliers, with the tools to bring pressure against undesirable corporate behaviour. This approach is very different from the ones adopted or proposed in other countries, which instead aim at integrating non-financial information in a disclosure document whose intended audience is primarily comprised of investors, analysts, and financial operators. $^{45}$

\section{Corporate behaviour, sustainability and disclosure}

The European Union, as well as other lawmakers from all over the world, have thus turned to non-financial disclosure as a possible driver to foster sustainable corporate behaviour. Commentators disagree on whether the European disclosure regime can effectively channel large corporations' powerful influence to promote positive social and environmental change. Some have pointed out that mandating disclosure on sustainability policies has the indirect, and yet important, effect of inducing their adoption in the first place, in the context of a widespread shift towards "corporate regulation" as a legislative tool. ${ }^{46}$ Reputational concerns are also likely to play a role in shaping corporate behaviour, especially since disclosure makes conduct more observable and perceptible. ${ }^{47}$ However, the comply or explain approach adopted by the Directive potentially undermines the effectiveness of these mechanisms, and the European rules are still far from embracing the level of detail and specificity that would allow audiences to make active use of non-financial information, particularly given the degree of variation permitted among the Member States. ${ }^{48}$

Considering the collective action problems that corporate constituencies traditionally face in making their voices heard by directors and managers, a greater commitment to transparency seems, in any case, a sensible choice. Investors, customers, suppliers, interest groups, and local communities are often too numerous, disaggregated, and heterogenous as a group to demand information, obtain it and, then, act upon

43 Recital (3) of Directive 2014/95/EU.

44 See, also for references, Bush T., Bauer R., Orlitzky M. Sustainable Development and Financial Markets: Old Paths and New Avenues. Business \& Society, 2016, Vol. 55, No. 3, pp. 304, 310-314.

45 Cf., for instance, the proposals advanced in the United States by Fisch (n. 14), pp. 923 ff.; and by Esty, Karpilow (n. 7), pp. $625 \mathrm{ff}$.

46 Chiu (n. 2), pp. 193 ff. On the potential of information regulation to enhance environmental policy goals, see, also for references, Esty, Karpilow (n. 7), pp. $631 \mathrm{ff}$.

47 Clarke B. The EU's Shareholder Empowerment Model in the Context of the Sustainable Companies Agenda. European Company Law, 2014, Vol. 11, No. 2, p. 105; Chiu (n. 2), p. 195.

48 See Quinn, Connolly (n. 12), pp. 19-20; de Roo (n. 12), pp. 279, 283-285. See also Esty, Karpilow (n. 7), pp. $680 \mathrm{ff}$. (criticizing Singapore's non-financial disclosure regime on the basis of its "comply or explain" approach, coupled with the lack of uniform sustainability metrics, would undermine comparability). 
it. ${ }^{49}$ When non-financial information is readily available, they are more likely to take it into account in their decision-making processes (for example, in making their investment or consumption choices, or in other respects).$^{50}$ Information may help interested parties to coordinate their actions more easily, even absent an explicit agreement to do so. If, for instance, non-financial disclosure were to reveal that a car manufacturer invested significantly less than its competitors in reducing polluting emissions, we would probably expect a decrease in sales even if the individual consumers did not agree on starting a boycott or their actions were not coordinated by environmentalist or other groups. ${ }^{51}$ To be sure, interest groups play an important role in bringing about change, and greater availability of information will, first of all, benefit those players, such as consumer or other associations, political actors, and large investors, who have the ability and resources to process it and bring pressure onto corporate management. However, one can easily expect that the benefits of increased information may extend beyond sophisticated or organized parties. The question is, however, what is the best way to make corporate entities produce valuable information that can actually be used by corporate constituencies or, even more generally, what is the most effective way to reach the intended audience of non-financial information regarding large corporations.

\section{Non-financial information and its audience: a call for effective stakeholder engagement}

The answer to the question is strictly connected to the more practical issue of whether non-financial information should be kept separate from financial information in the entities' reports or whether the two should be comprised in a single, comprehensive, and to the extent possible integrated disclosure. Arguably, in fact, putting non-financial information within or next to financial disclosure targets shareholders and investors generally, but may not as adequately reach interest groups or (individual) stakeholders at large. ${ }^{52}$

More broadly, despite the Guidelines' indication to provide understandable nonfinancial information "using plain language and consistent terminology, avoiding boilerplate" language "and, where necessary, providing definitions for technical terms", ${ }^{33}$ one may doubt that unsophisticated parties will actually read and understand nonfinancial disclosure, regardless of where it is provided. This is relevant because, even

49 See, in the context of human rights protection, de Roo (n. 12), pp. 279-280 (arguing, however, that "bridging the information gap by mandatory disclosure does not independently lead market participants to hold companies into account”).

50 See, generally on the pressure from external stakeholders, Esty, Karpilow (n. 7), pp. 632 f.

51 Cf. Konar S., Cohen M. A. Why Do Firms Pollute (and Reduce) Toxic Emissions? p. 14. Available at: https://www.oecd.org/env/outreach/33947723.pdf [last viewed May 7, 2019].

52 In this respect, see Bassen A., Kovács A. M. Environmental, Social and Governance Key Performance Indicators from a Capital Market Perspective. Zeitschrift für Wirtschafts- und Unternehmensethik, 2008, Vol. 9, No. 2, p. 183 (observing that voluntary non-financial disclosure is "complex and sometimes hard to understand and implement even for sophisticated users").

53 Para. 3.2, Guidelines. 
though comparable problems also arise in relation to financial information, the latter is filtered and rendered more accessible by a well-functioning network of information intermediaries (such as analysts, credit rating agencies, auditing firms, economic journalists, and so forth). By contrast, although a similar network also exists with respect to non-financial information, one may argue that it is not yet fully established. This is due to many interrelated factors, including, importantly, the fact that the rules, metrics, and standards for non-financial disclosure are provided by many organizations and standard setters, varying from one another in several respects. ${ }^{54}$ There is still debate on which environmental, social, and governance issues and practices actually impact financial performance; ${ }^{55}$ and, as the Directive implicitly recognizes by referring to different national and international frameworks and standards, the picture of what the best practice is and how it should be implemented is still fragmented to some extent. There is, in other words, less consensus on how disclosure should be drafted and presented to its audience.

More intuitively, companies do not communicate with their stakeholders only or primarily through management reports and "semi-financial" statements. Consumers, suppliers, local communities, and even public authorities are often reached through different means, which, in the newly established regulatory framework on non-financial disclosure, do not seem to play a part. This is implicitly confirmed by the practice of some companies to voluntarily provide different types of non-financial disclosure, distinguishing on the basis of the intended audience. ${ }^{56}$ Different stakeholders might be interested in different sets of information or might have different information needs, only partly overlapping, ${ }^{57}$ and in the current regime the balancing of these different needs and the practical solutions are entirely left to the Member States and to the individual reporting entities.

The choice of the European lawmaker is, in fact, somewhat hybrid with respect to the relevant audience of the newly introduced disclosure obligations. There are several factors that call for greater integration of financial and non-financial information, to the primary benefit of current and potential investors. The discipline on

54 See, e.g., Fisch (n. 14), pp. 944 ff.; Herzig, Schaltegger (n. 12), pp. 158-159.

55 See, e.g., Orlitzky M. Corporate Social Performance and Financial Performance. a Research Synthesis. In: The Oxford Handbook of Corporate Social Responsibility. Oxford: Oxford University Press, 2008, pp. 113 ff.; Esty, Karpilow (n. 7), pp. 639 ff. (especially 646 f.). See also Nelling E., Webb E. Corporate social responsibility and financial performance: the "virtuous circle" revisited. Review of Quantitative Finance and Accounting, 2009, Vol. 32, No. 2, pp. 197 ff.; Alexander G. J., Buchholz R. A. Corporate Social Responsibility and Market Performance. Academy of Management Journal, 1978, Vol. 21, No. 3, pp. $479 \mathrm{ff}$.

56 Interestingly, in 2017, Apple prepared different types of non-financial disclosure: an environmental responsibility report, a supplier responsibility report, and website information on inclusion and diversity issues. See, in this respect, Fisch (n. 14), p. 944. See also Herzig, Schaltegger (n. 12), pp. 155-156 (noting that, in the framework of voluntary disclosure, companies have taken disparate approaches and some have chosen to prepare different reports for different stakeholders, dealing with specific aspects of corporate sustainability).

57 See, generally, Herzig, Schaltegger (n. 12), p. 157 (reporting that sustainability disclosure doesn't always meet investors' needs, that "only a limited number of systematic and comprehensive studies has been conducted on stakeholders' reception of and attitudes towards sustainability disclosure practice", and that "lack of target group orientation creates a risk of information overload"). 
non-financial disclosure is, for instance, introduced within the broader framework of financial statements regulation; and the type of the required disclosure significantly covers business and performance-related areas, such as the entity's business model and the principal risks that the undertaking's operations pose in relation to environmental, social, employee, human rights, anti-corruption, and bribery matters. In many cases these risks may significantly affect performance. The Guidelines, for example, indicate that relevant information may, depending on the circumstances, concern the expected impact of "science-based climate change scenarios" on the entity's strategies and activities..$^{58}$ a company may thus decide to publicly disclose the information on environmental issues either because climate change can endanger its operations (think of a company supplying water in territories growingly affected by droughts), or because it can increase profitability (an oil and gas producer may, by way of example, benefit from the melting of sea ice in the Artic region due to the availability of new drilling opportunities). In these respects, investors seem to be, if not the only intended audience of the disclosure, certainly its main recipients.

However, the Directive itself makes reference to the interests of stakeholders other than investors, ${ }^{59}$ and the Guidelines specify that the non-financial statement should consider the information needs of all relevant stakeholders. These may include "investors, workers, consumers, suppliers, customers, local communities, public authorities, vulnerable groups, social partners and civil society", ${ }^{60}$ but the list does not seem exclusive. Depending on the particular business or industry, other constituencies may be affected by corporate action or may be interested in acquiring non-financial information on the entity's activities; and extending the benefit of disclosure to all can certainly increase the chances to promote virtuous corporate behaviour.

Despite the admirable intent of the European lawmaker, there are, however, reasons to doubt that this is more than just a tentative first move. The main problem is that the current disclosure system does not seem to target any corporate constituency with any degree of specificity, with the exclusion of investors. The hope is hence that the greater stakeholder engagement that the Guidelines call for, by inviting reporting entities to gain a better understanding of stakeholders' interests and concerns in order to determine the content and the materiality of the disclosure, ${ }^{61}$ will partially downsize the problem, and that the implementing measures adopted at the Member State level also improve the channels of communication between the parties involved. Especially

58 Para. 3.4, Guidelines.

59 See, e. g., recital (3) of Directive 2014/95/EU. See, in this respect, Chiu (n. 2), p. 199 (also observing that Directive 2014/95/EU tries to get away from a shareholder-centric focus in order to embrace a more stakeholder-oriented perspective).

60 Paras 3.2 and 3.5, Guidelines.

${ }^{61}$ The Guidelines refer to shareholder engagement in many different respects: see para. 3.1 (which, among the factors to consider in determining whether information is material, includes "the interests and expectations of the relevant stakeholders", with whom companies are expected to engage); para. 3.2 (observing that "[i]nformation can be made fairer and more accurate through... effective stakeholder engagement"); para. 3.5 (requiring companies to report on "their engagement with relevant stakeholders, and how their information needs are taken into account"); para. 4 (according to which the specific themes and the material information to include in the disclosure should be identified also by engaging with the relevant stakeholders). 
where the relevant constituencies lack the investigatory tools or the power of persuasion of regulatory bodies and agencies, effective stakeholder engagement is, in fact, all the more important.

\section{Conclusion}

The introduction at the European level of new reporting obligations on nonfinancial information is an important step not only towards holding large enterprises accountable for the impact of their operations on the environment, workers, human rights, and society as a whole, providing them an incentive to internalize the costs of their potentially harmful actions, but also to promote innovation, encouraging companies to find creative ways to help solve pressing social and environmental problems. Enhancing disclosure on non-financial issues may, after all, push companies to imitate the successful practices employed by competitors and to engage in a fruitful race to the top. ${ }^{62}$

The European legislative framework is, however, only a first step. Unlike financial disclosure, rules, standards, and metrics for non-financial disclosure are still to some extent underdeveloped. Greater specificity and particularity in the content of the disclosure obligations is probably necessary, at least if we want disclosure to effectively guide corporate behaviour. Moreover, the current legislative framework does not seem to be tailored to address the variety and heterogeneity of the possible interested parties. While financial disclosure is essentially directed to current and potential investors, non-financial disclosure has greater chances to meet its goal when it successfully reaches all interested parties, which significantly also include employees, customers, suppliers, local communities, and a broad range of public authorities. Adjusting nonfinancial disclosure to the needs of its intended recipients is perhaps the most pressing task to bring about change and facilitate private and public enforcement. ${ }^{63}$ In this perspective, stakeholder engagement offers a promising and still evolving way forward.

\section{BIBLIOGRAPHY}

\section{Literature}

1. Alexander G. J., Buchholz R. A. Corporate Social Responsibility and Market Performance. Academy of Management Journal, 1978, Vol. 21, No. 3, pp. 479-486.

2. Angelici C. Divagazioni sulla "responsabilità sociale" d'impresa. Rivista delle società, 2018, No. 1, pp. 3-19.

3. Bassen A., Kovács A. M. Environmental, Social and Governance Key Performance Indicators from a Capital Market Perspective. Zeitschrift für Wirtschafts- und Unternehmensethik, 2008, Vol. 9, No. 2, pp. 182-192.

62 See Esty, Karpilow (n. 7), pp. 631 f., 634, 685 f.

${ }_{63}$ Recently, on the enforcement within the Italian legal system of the non-financial disclosure obligations introduced by Directive 2014/95/EU, see Rimini E. I valori della solidarietà sociale nelle dichiarazioni non finanziarie. Analisi Giuridica dell'Economia, 2018, No. 1, pp. 196-198. 
4. Brakman Reiser D. Benefit Corporations - a Sustainable Form of Organization? Wake Forest Law Review, 2011, Vol. 46, No. 3, p. 591.

5. Bush T., Bauer R., Orlitzky M. Sustainable Development and Financial Markets: Old Paths and New Avenues. Business \& Society, 2016, Vol. 55, No. 3, pp. 303-329.

6. Carroll A. B. A History of Corporate Social Responsibility: Concepts and Practices. In: The Oxford Handbook of Corporate Social Responsibility. Oxford: Oxford University Press, 2008, pp. 19-46.

7. Chiu I. H.-Y. Unpacking the Reforms in Europe and the UK Relating to Mandatory Disclosure in Corporate Social Responsibility: Instituting a Hybrid Governance Model to Change Corporate Behaviour? European Company Law Journal, 2017, Vol. 14, No. 5, pp. 193-208.

8. Clarke B. The EU's Shareholder Empowerment Model in the Context of the Sustainable Companies Agenda. In: European Company Law, 2014, Vol. 11, No. 2, pp. 103-106.

9. Eldar O. The Role of Social Enterprise and Hybrid Organizations. Columbia Business Law Review, 2017, No. 1, pp. 92-194.

10. Esty D. C., Karpilow Q. Harnessing Investor Interest in Sustainability: The Next Frontier in Environmental Information Regulation. In: Yale Journal on Regulation, 2019, Vol. 36, No. 2, pp. 625-692.

11. Fisch J. E. Making Sustainability Disclosure Sustainable. The Georgetown Law Journal, 2019, Vol. 107, No. 4, pp. 923-966.

12. Gao X., Ritter J. R., Zhu Z. Where Have All the IPOs Gone? Journal of Financial and Quantitative Analysis, 2013, Vol. 48, No. 6, pp. 1663-1692.

13. Herzig C., Schaltegger S. Corporate Sustainability Reporting. In: Sustainability Communication. Interdisciplinary Perspectives and Theoretical Foundations. Dordrecht: Springer, 2011, pp. 151-169.

14. Konar S., Cohen M. A. Why Do Firms Pollute (and Reduce) Toxic Emissions? Available at: https://www.oecd.org/env/outreach/33947723.pdf [last viewed May 7, 2019].

15. Nelling E., Webb E. Corporate social responsibility and financial performance: the "virtuous circle" revisited. Review of Quantitative Finance and Accounting, 2009, Vol. 32, No. 2, pp. 197-209.

16. Orlitzky M. Corporate Social Performance and Financial Performance. a Research Synthesis. In: The Oxford Handbook of Corporate Social Responsibility. Oxford: Oxford University Press, 2008, pp. 113-136.

17. Porter M. E., Kramer M. R. Strategy and Society: The Link Between Competitive Advantage and Corporate Social Responsibility. In: Harvard Business Review, 2006, Vol. 84, No. 12, pp. 78-92.

18. Quinn J., Connolly B. The Non-Financial Information Directive: An Assessment of Its Impact on Corporate Social Responsibility. In: European Company Law Journal, 2017, Vol. 14, No. 1, pp. 15-21.

19. Rimini E. I valori della solidarietà sociale nelle dichiarazioni non finanziarie. Analisi Giuridica dell'Economia, 2018, No. 1, pp. 187-200.

20. Rönnegard D., Craig Smith N. Shareholder Primacy vs. Stakeholder Theory: The Law as Constraint and Potential Enabler of Stakeholder Concerns. Available at: https://papers.ssrn.com/ sol3/papers.cfm?abstract_id=3165992 [last viewed May 6, 2019].

21. Roo K. H. M., de. The Role of the EU Directive on Non-Financial Disclosure in Human Rights Reporting. European Company Law, 2015, Vol. 12, No. 6, pp. 278-285. 
22. Szabó D. G., Sørensen K. E. New EU Directive on the Disclosure of Non-Financial Information (CSR). European Company and Financial Law Review, 2015, Vol. 12, No. 3, pp. 307-340.

23. Zhakypova A. Dissecting Corporate Sustainability Reporting: VW Emissions Scandal case. Available at: https://nature.berkeley.edu/classes/es196/projects/2016final/ZhakypovaA_2016.pdf [last viewed May 6, 2019].

\section{Normative acts}

24. Directive 2014/95/EU of 22 October 2014 amending Directive 2013/34/EU as regards disclosure of non-financial and diversity information by certain large undertakings and groups. Available at: https://eur-lex.europa.eu/legal-content/EN/TXT/PDF/?uri=CELEX:32014L $0095 \&$ from $=$ EN [last viewed May 6, 2019].

25. Directive $2013 / 34 / E U$ of 26 June 2013 on the annual financial statements, consolidated financial statements and related reports of certain types of undertakings, amending Directive 2006/43/EC of the European Parliament and of the Council and repealing Council Directives 78/660/EEC and 83/349/EEC. Available at: https://eur-lex.europa.eu/legal-content/EN/ $\mathrm{TXT} / \mathrm{PDF} /$ ?uri=CELEX:32013L0034\&from=EN [last viewed May 6, 2019].

26. Italian Law 28 December 2015, No. 2008. Available at: https://www.gazzettaufficiale.it/eli/ $\mathrm{id} / 2015 / 12 / 30 / 15 \mathrm{G} 00222 / \mathrm{sg}$ [last viewed May 6, 2019].

27. Model Benefit Corporation Legislation (17 April 2017). Available at: https://benefitcorp.net/ sites/default/files/Model\%20benefit\%20corp\%20legislation\%20_4_17_17.pdf [last viewed May $6,2019]$.

\section{Judicial opinions}

28. Kasky v. Nike, Inc., 45 P.3d 243 (Cal. 2002).

\section{Other sources}

29. European Commission. Communication "Guidelines on non-financial reporting (methodology for reporting non-financial information)”, 2017/C 215/01. Available at: https://eur-lex.europa. eu/legal-content/EN/TXT/PDF/?uri=OJ:C:2017:215:FULL\&from=EN [last viewed May 7, 2019].

30. European Commission. Proposal for a Directive of the European Parliament and of the Council amending Council Directives 78/660/EEC and 83/349/EEC as regards disclosure of non-financial and diversity information by certain large companies and groups, $\operatorname{COM}(2013) 207$ final. Available at: https://eur-lex.europa.eu/LexUriServ/LexUriServ. do?uri=COM:2013:0207:FIN:EN:PDF [last viewed May 7, 2019].

31. European Commission. Impact Assessment Accompanying the Document Proposal for a Directive of the European Parliament and of the Council amending Council Directives 78/660/EEC and $83 / 349 / \mathrm{EEC}$ as regards disclosure of non-financial and diversity information by certain large companies and groups, SWD(2013) 127 final. Available at: https://eur-lex.europa.eu/ legal-content/EN/TXT/PDF/?uri=CELEX:52013SC0127\&from=EN [last viewed May 7, 2019].

32. European Commission. Communication to the European Parliament, the Council, the European Economic and Social Committee and the Committee of the Regions on "A renewed EU strategy 2011-14 for Corporate Social Responsibility”, $\operatorname{COM(2011)~} 681$ final. Available at: https:// eur-lex.europa.eu/legal-content/EN/TXT/PDF/?uri=CELEX:52011DC0681\&from=EN [last viewed May 7, 2019]. 
33. European Commission. Communication to the European Parliament, the Council and the European Economic and Social Committee "Implementing the Partnership for Growth and Jobs: Making Europe a Pole of Excellence on Corporate Social Responsibility”, $\operatorname{COM}(2006) 136$ Final. Available at: https://eur-lex.europa.eu/LexUriServ/LexUriServ. do?uri=COM:2006:0136:FIN:en:PDF [last viewed May 7, 2019].

34. United Nations Environment Programme (UNEP), Global Reporting Initiative (GRI), KPMG, Unit for Corporate Governance in Africa. Carrots and sticks - Sustainability reporting policies worldwide - today's best practice, tomorrow's trends. 2010. Available at: https://assets.kpmg/ content/dam/kpmg/pdf/2016/03/Carrots-and-Sticks-11-12-2015.pdf [last viewed May 6, 2019]. 